\title{
Coping behavior of children undergoing chemotherapy
}

\section{Comportamento de coping de crianças em quimioterapia}

\author{
Flávia Helena Pereira PADOVANI 1 iD 0000-0002-3171-778X \\ Guilherme Costa LOPES ${ }^{2}$ (D) 0000-0002-5090-9357 \\ Gimol Benzaquen PEROSA ${ }^{1}$ (ID) 0000-0003-3139-8886
}

\begin{abstract}
The diagnosis of childhood cancer, the treatment itself and its sequelae can be considered as stressful events in the child's life, requiring the use of coping strategies. The aim of this study was to describe the coping behaviors used by children and adolescents with cancer undergoing chemotherapy treatment, separated by sex, age and type of cancer. A total of 15 children and adolescents, from 6 to 12 years old, of both sexes, answered the Hospitalization Coping Strategies instrument regarding coping behaviors. Participants referred to behaviors with greater chances of an adaptive outcome: watching TV, talking, and taking their medicines. There were differences in the coping behaviors regarding sex, age, and types of cancer. These differences highlight the need for personalized interventions that include specific characteristics to facilitate the child's adaptation to the treatment.
\end{abstract}

Keywords: Adaptation, psychological; Drug therapy; Neoplasms; Psychology, child.

\section{Resumo}

O diagnóstico de câncer infantil, o próprio tratamento e suas sequelas podem ser considerados eventos estressores na vida de uma criança, demandando o uso de estratégias de enfretamento ou coping. O objetivo do estudo foi descrever os comportamentos de coping utilizados por crianças e adolescentes com câncer frente ao tratamento quimioterápico, diferenciadas quanto ao sexo, a idade e ao tipo de câncer que enfrentam. Quinze crianças e adolescentes, de seis a doze anos de idade, de ambos os sexos, responderam o instrumento de Avaliação das Estratégias de Enfrentamento da Hospitalização sobre os comportamentos de enfrentamento. Os participantes referiram recorrer a comportamentos

$\checkmark \nabla \nabla$

${ }^{1}$ Universidade Estadual Paulista, Faculdade de Medicina de Botucatu, Departamento de Neurologia, Psicologia e Psiquiatria. Av. Prof. Mário Rubens Montenegro, s/n., Campus de Botucatu, 18618-687, Botucatu, SP, Brasil. Correspondence to: F.H.P. PADOVANI. E-mail: $<$.padovani@unesp.br>.

2 Faculdades Integradas de Bauru. Bauru, SP, Brasil.

Support: Coordenação de Aperfeiçoamento de Pessoal de Nível Superior (2nd author Master's Scholarship).

Article based on the dissertation of G.C. LOPES, entitled "A compreensão da doença, do tratamento quimioterápico e as formas de enfrentamento de crianças com câncer". Universidade Estadual Paulista, 2016.

How to cite this article

Padovani, F. H. P., Lopes, G. C., \& Perosa, G. B. (2021). Coping behavior of children undergoing chemotherapy. Estudos de Psicologia (Campinas), 38, e190121. https://doi.org/10.1590/1982-0275202138e190121 
com maiores chances de um desfecho adaptativo: assistir televisão, conversar e tomar remédio. Com relação aos comportamentos de enfrentamento relatados, foram encontradas diferenças quanto ao sexo, idade e tipos de câncer enfrentado, que sinalizam a necessidade de intervenções personalizadas que contemplem características específicas para facilitar a adaptação da criança ao tratamento.

Palavras-chave: Adaptação psicológica; Tratamento farmacológico; Neoplasias; Psicologia da criança.

Children with cancer are exposed to frequent and extensive hospitalizations, in addition to invasive and unpleasant procedures, the most striking ones being the side effects of chemotherapy (Cicogna, Nascimento, \& Lima, 2010).

In a study with adolescents, it was observed that chemotherapy was more frightening than cancer itself due to weakness, limitations in the performance of daily activities, impaired sleep rhythm and appetite, in addition to the deterioration of the self-image, especially alopecia, for female patients (Jesus \& Gonçalves, 2006). Even when children have already finished their treatment and are seen in outpatient follow-up, they report the desire to look like they did before and resume the activities that needed to be interrupted (Lanza \& Valle, 2014). On the other hand, children and adolescents recognized that the treatment, although permeated with adversities, meant the possibility of living without the disease (Cicogna et al., 2010; Lanza \& Valle, 2014; Souza, Reichert, Sá, Assolini, \& Collet, 2014).

Thus, the diagnosis of childhood cancer, the treatment itself and its sequelae can be considered stressful events in the child's life, that is, a situation perceived by individuals as overloading or exceeding their social and personal resources. Faced with these stressful situations, the child uses different ways to change or reduce the sources of stress, in a process called coping or coping strategies (Lazarus \& Folkman, 1984; Vasconcelos \& Nascimento, 2016). Coping would be the set of cognitive, emotional, and behavioral actions, used by individuals in a conscious and deliberate way in order to adapt to adverse or stressful situations (Antoniazzi, Dell'Aglio, \& Bandeira, 1998; Lazarus \& Folkman, 1984).

With a developmental proposal of stress-coping analysis, the Motivational Theory of Coping (MTC) allows the identification of coping patterns that depend on age, as well as assessing the role of developmental changes in the use of certain coping strategies (Ramos, Enumo, \& Paula, 2015; Vasconcelos \& Nascimento, 2016; Zimmer-Gembeck \& Skinner, 2011).

To understand coping responses, the MTC proposes a hierarchical model composed of three different levels. At the base of the coping structure are the "instances or coping behaviors", the individuals' responses (what they do or think) when dealing with stressful situations. These behaviors can be organized into categories called "coping strategies", based on their purpose, meaning or functional value. At their highest level there are 12 macro categories or "families" that have in common a particular type of assessment and a typical pattern of behavior, emotion, and orientation and that end up characterizing a tendency for action. These are: self-confidence, search for support, problem solving, search for information, adjustment/adaptation, negotiation, delegation, social isolation, helplessness, avoidance, submission, and opposition (Ramos et al., 2015; Vasconcelos \& Nascimento, 2016; Zimmer-Gembeck \& Skinner, 2011).

This theoretical model was used in several Brazilian studies with sick or hospitalized children, including some with cancer (Caprini \& Motta, 2017; Carnier, Padovani, Perosa, \& Rodrigues, 2015; Garioli, Paula, \& Enumo, 2019; Hostert, Motta, \& Enumo, 2015; Oliveira, Enumo, \& Paula, 2017; Pagung, Canal, Missawa, \& Motta, 2017). In general, the children in these studies reported the use of behaviors with a greater chance of a positive outcome in the adaptive process, such as: taking medicines, talking, watching television, and playing. However, in the study by Caprini and Motta (2017), it was found that children from 6 to 12 years 2 old, right after the diagnosis of cancer, in addition to adaptive strategies, resorted to less adaptive strategies, 
such as rumination. It was also observed that, compared to those with other conditions, children with cancer reported more helplessness (Motta et al., 2015), isolation and opposition (Pagung et al., 2017).

To assess coping strategies, there are few instruments available that directly consider the point of view of hospitalized children and adolescents. In the international literature, Kidscope, a short and structured self-report questionnaire (Spirito, Stark, \& Williams, 1989), has been widely used in research. Likewise, at the national level, the Assessment Tool for Coping with Hospitalization Strategies (ACH), developed by Motta and Enumo (2004), which is based on the theoretical framework of MTC, has been widely used to assess coping in hospitalized children (Motta et al., 2015). In view of the above, especially the scarcity of studies focused on coping strategies for children undergoing chemotherapy, the objective of the present study was to describe the coping behaviors used by children with cancer in relation to chemotherapy, separated by sex, age and type of cancer.

\section{Method}

This is a descriptive, cross-sectional study.

\section{Participants}

A convenience sample was created with the following inclusion criteria: children diagnosed with cancer, of both sexes, from six to twelve years old, undergoing intravenous chemotherapy or who finished their intravenous chemotherapy treatment less than five months prior to the date of this study, continuing with oral chemotherapy and outpatient follow-up for control. The participating children came from two cancer treatment institutions in the interior of the state of São Paulo, which are centers of excellence, both linked to the Sistema Único de Saúde (Unified Health System).

Among the eligible children, two were excluded for not having physical conditions (very weak, feeling pain). There was also a refusal to participate by a legal guardian. The final sample consisted of fifteen participants, with eleven undergoing intravenous chemotherapy and four individuals undergoing oral chemotherapy.

\section{Ethical considerations}

This study was approved by the Research Ethics Committee of the university - Certificado de Apresentação para Apreciação Ética (CAAE, Presentation Certificate for Ethical Appreciation) protocol number 34606314.4.0000.5411. For its performance, the ethical guidelines proposed by Resolution 466/2012 were strictly complied with.

\section{Instruments}

For data collection, the $\mathrm{ACH}$, developed by Motta and Enumo (2004), was used to identify which behaviors are used by children aged 6 to 12 to face hospitalization. The instrument consists of 20 pictures with scenes that represent different coping behaviors: playing, singing and dancing, watching TV, talking, listening to music, studying, reading comics, seeking information, taking medicines, crying, feeling angry, hiding, feeling sad, feeling helpless, blackmailing, thinking about running away, feeling guilty, feeling afraid, thinking about miracles and praying. Faced with these pictures, the child states how often they feel each of the behaviors, based on a Likert-type scale, which ranges from never (0) to always (4) (Caprini \& Motta, 2017). Considering the objective of the present study, children were instructed to identify the coping behaviors they used when going to the hospital for chemotherapy sessions. 


\section{Procedures}

After explaining the research, if the child and the legal guardian consented to participate, the guardian was asked to sign the Informed Consent Term and the procedure was started. Sociodemographic data were collected with the child's guardian. With the child, rapport was initially established with the use of playful materials to address their experiences about cancer and chemotherapy. Then, the ACH was applied to assess coping behaviors. Data collection took place in the very environment where the children's chemotherapy sessions were held which, in addition to the individual reclining chairs, also had a TV, a video game, DVDs with movies, graphic material, books and games. Guardians were often present because they preferred not to leave their children or were absent only for a few minutes.

\section{Data analysis}

At first, the characterization of the sample was carried out, in terms of absolute and relative frequency, and then, a descriptive statistical analysis of the data related to coping behaviors was carried out. According to the rules of the instrument, the sum of the values attributed by the children for each of the 20 behaviors presented in the pictures was calculated, making it possible to visualize which scenes were most chosen and with what intensity. Then, the mean of the behaviors reported by the children, separated in terms of sex (girls versus boys), age (6-9 years versus 10-12 years) and type of cancer (leukemia/lymphoma versus solid tumor) was calculated.

\section{Results}

Most of the participating children were girls $(n=9 ; 60.0 \%)$, from six to nine years old $(n=8 ; 53.3 \%)$. As for the disease, $46.7 \%(n=7)$ were diagnosed as having different types of solid tumors, $46.7 \%(n=7)$ had leukemia and one child (6.6\%) had lymphoma. Most participants were still undergoing chemotherapy when data collection was performed, however, four children (26.7\%) had already finished their treatments and were undergoing outpatient exams, having had the last chemotherapy session in a maximum of five months prior to the day of data collection.

Regarding the individuals who were with them at the moment of data collection, the vast majority were the mothers $(n=10 ; 66.7 \%)$, and in the other cases they were the children's fathers, grandmothers, and aunts. The mean age of these individuals was 39 years, most did not complete high school $(n=11 ; 73.3 \%)$, were in a stable union $(n=13 ; 86.7 \%)$ and reported needing support for taking care of their children and for doing day-to-day tasks ( $n=13 ; 86.7 \%$ ) (Table 1$)$.

The most frequent coping behaviors related to chemotherapy were: watching TV, talking and taking medicines. On the other hand, the least frequent were: thinking about running away, hiding and studying (Figure 1).

When comparing the types of behavior used by children of different sexes, it can be seen, in Figure 2, that talking $(M=3.3)$ and watching TV $(M=2.3)$, were, respectively, the preferred behaviors by girls, while boys reported taking medicines more frequently $(M=3.3)$, followed by watching TV $(M=3.0)$ and playing $(M=3.0)$.

When comparing the coping behaviors used by children of different ages, watching TV $(M=3.71)$ and playing $(M=3.57)$ were the behaviors most frequently reported by younger children, while talking

$4 \quad(M=3.25)$ and listening to music $(M=2.87)$ were mostly reported by older children (Figure 3$)$. 
Table 1

Sociodemographic characteristics of children $(n=15)$ and their legal guardians ( $n=15)$. Botucatu and Bauru (SP), Brazil, 2015

\begin{tabular}{|c|c|c|}
\hline Characteristic & $f$ & $\%$ \\
\hline \multicolumn{3}{|l|}{ Sex (child) } \\
\hline $\begin{array}{l}\text { Male } \\
\text { Female }\end{array}$ & $\begin{array}{l}6 \\
9\end{array}$ & $\begin{array}{l}40.0 \\
60.0\end{array}$ \\
\hline \multicolumn{3}{|l|}{ Age (years) } \\
\hline $\begin{array}{c}6-9 \\
10-12\end{array}$ & $\begin{array}{l}8 \\
7\end{array}$ & $\begin{array}{l}53.3 \\
46.7\end{array}$ \\
\hline \multicolumn{3}{|l|}{ Type of cancer } \\
\hline $\begin{array}{l}\text { Solid tumor } \\
\text { Leukemia } \\
\text { Lymphoma }\end{array}$ & $\begin{array}{l}7 \\
7 \\
1\end{array}$ & $\begin{array}{c}46.7 \\
46.7 \\
6.6\end{array}$ \\
\hline \multicolumn{3}{|l|}{ Legal guardian } \\
\hline $\begin{array}{l}\text { Mother } \\
\text { Others }\end{array}$ & $\begin{array}{c}10 \\
5\end{array}$ & $\begin{array}{l}66.7 \\
33.3\end{array}$ \\
\hline \multicolumn{3}{|c|}{ Legal guardian's educational level } \\
\hline $\begin{array}{l}\text { Incomplete high school } \\
\text { Complete high school }\end{array}$ & $\begin{array}{c}11 \\
4\end{array}$ & $\begin{array}{l}73.3 \\
26.7\end{array}$ \\
\hline \multicolumn{3}{|l|}{ Stable union } \\
\hline $\begin{array}{l}\text { Yes } \\
\text { No }\end{array}$ & $\begin{array}{c}13 \\
2\end{array}$ & $\begin{array}{l}86.7 \\
13.3\end{array}$ \\
\hline \multicolumn{3}{|c|}{ Social support for coping and taking care of the child } \\
\hline $\begin{array}{l}\text { Yes } \\
\text { No }\end{array}$ & $\begin{array}{c}13 \\
2\end{array}$ & $\begin{array}{l}86.7 \\
13.3\end{array}$ \\
\hline
\end{tabular}

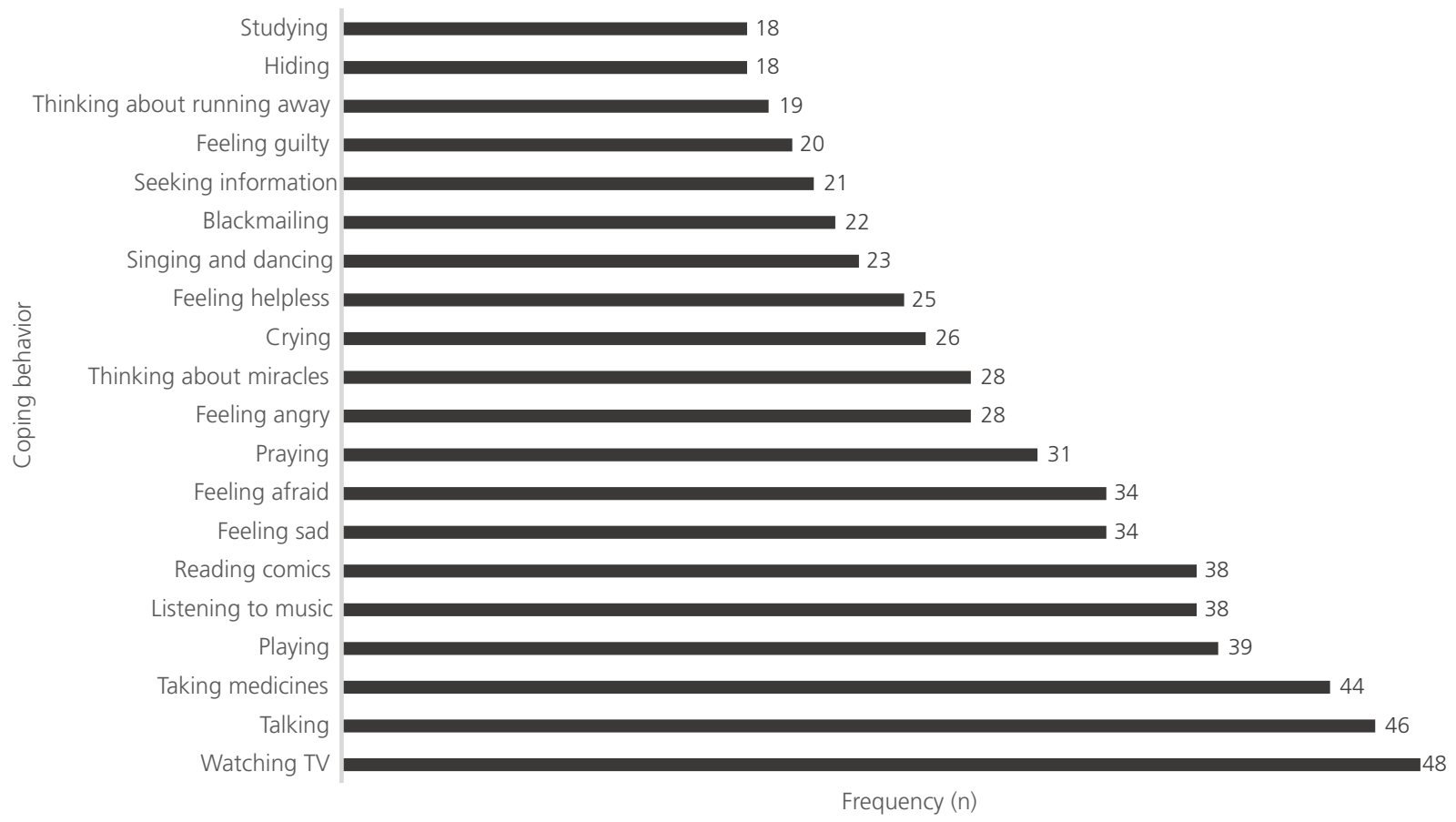

Figure 1. Frequency of chemotherapy coping behaviors reported by children with cancer. Botucatu and Bauru (SP), Brazil, 2015. 


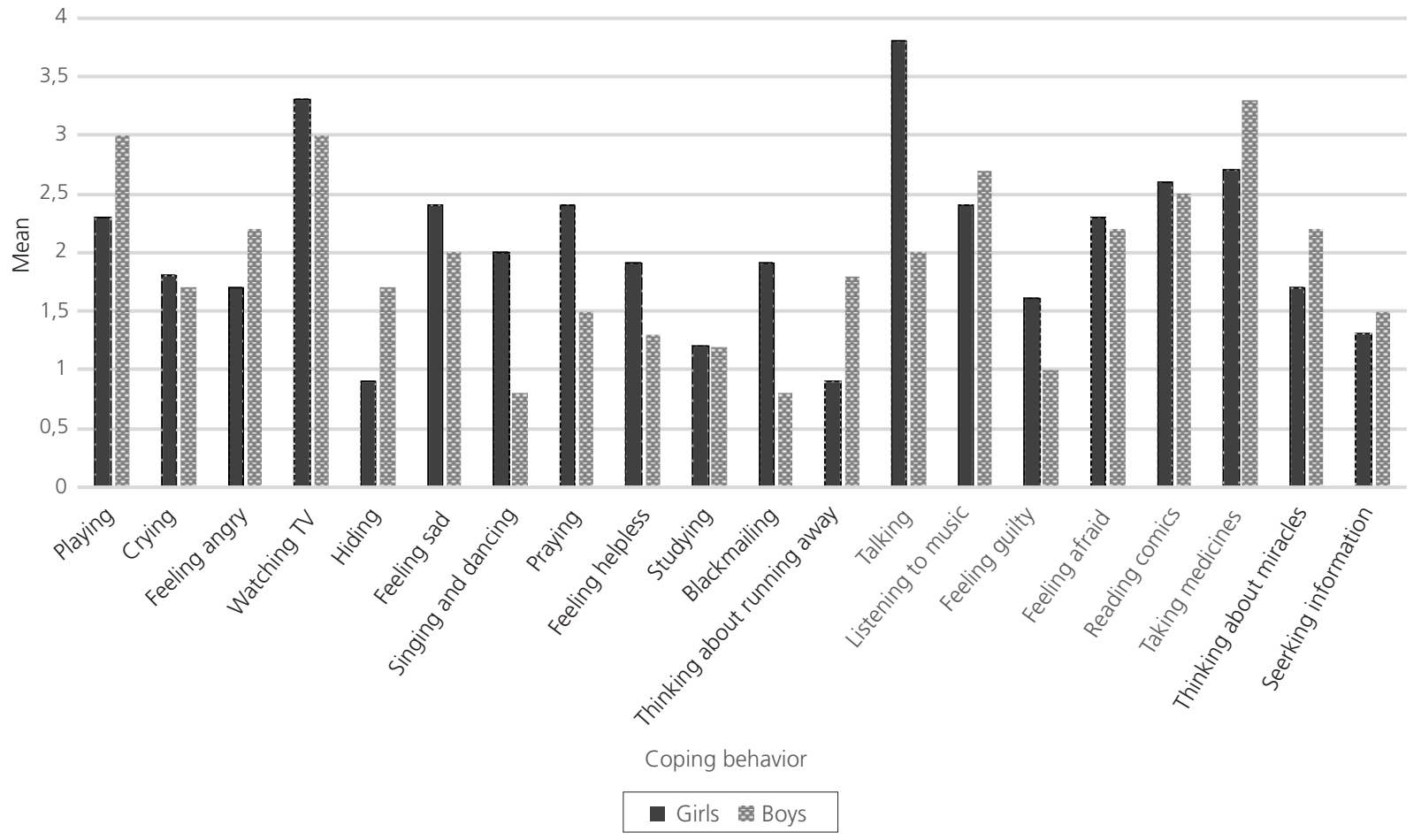

Figure 2. Mean of chemotherapy coping behaviors reported by children with cancer, separated by sex (girls versus boys). Botucatu and Bauru (SP), Brazil, 2015.

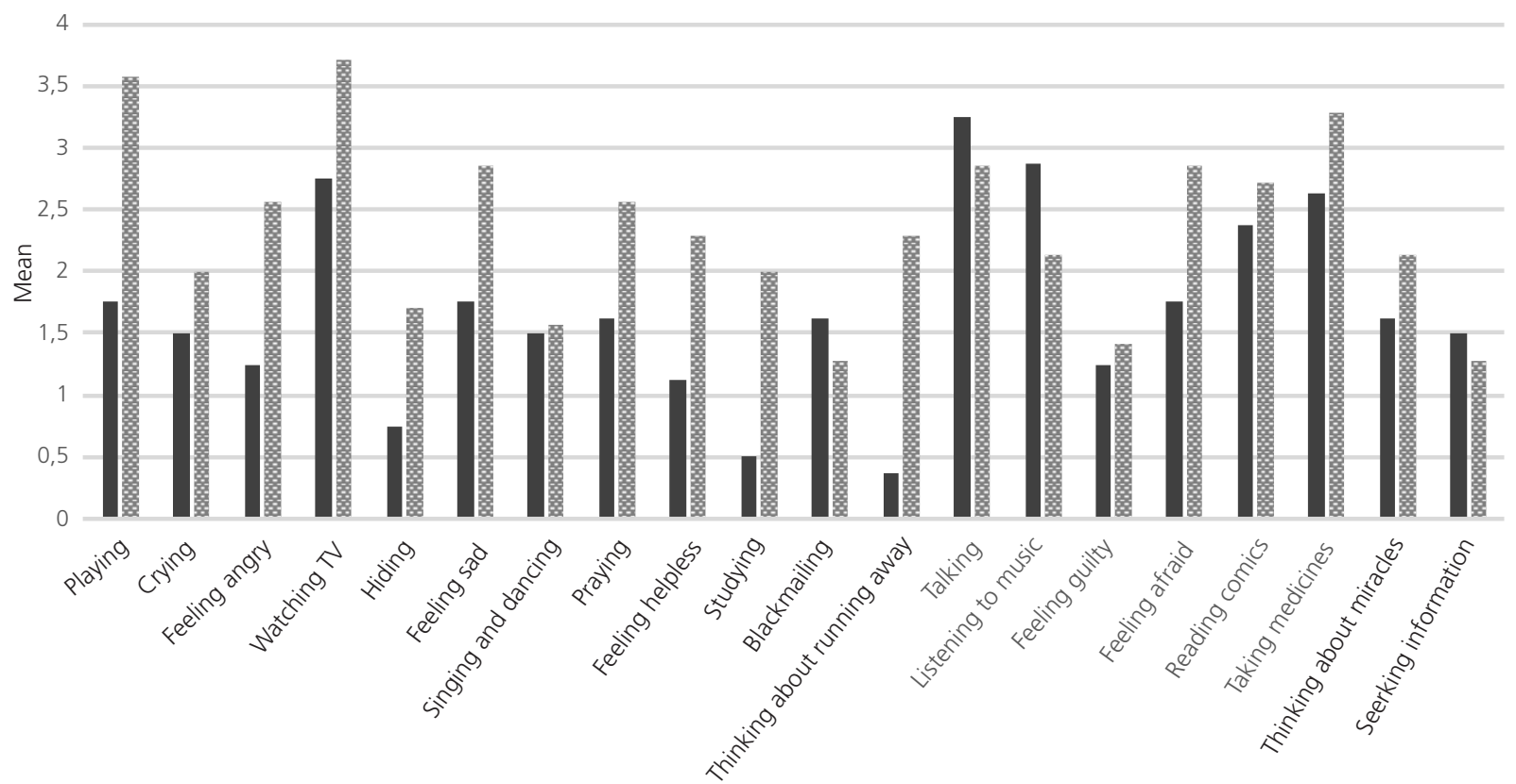

Coping behavior

- 10-12 years 6-9 years

Figure 3. Mean of chemotherapy coping behaviors reported by children with cancer, separated by age (6-9 years versus 10-12 years). Botucatu and Bauru (SP), Brazil, 2015. 
Figure 4 illustrates the frequency of coping behaviors used by children with different types of cancer. Talking $(M=3.28)$ was the preferred behavior by children with solid tumors, and watching TV $(M=3.25)$, by children with leukemia/lymphoma. In a comparative way, it is noteworthy that children with leukemia/lymphoma reported feeling helpless more frequently $(M=2.12 \times M=1.0)$, and those with solid tumors reported thinking about miracles $(M=2.28 \times M=1.25)$ more frequently.

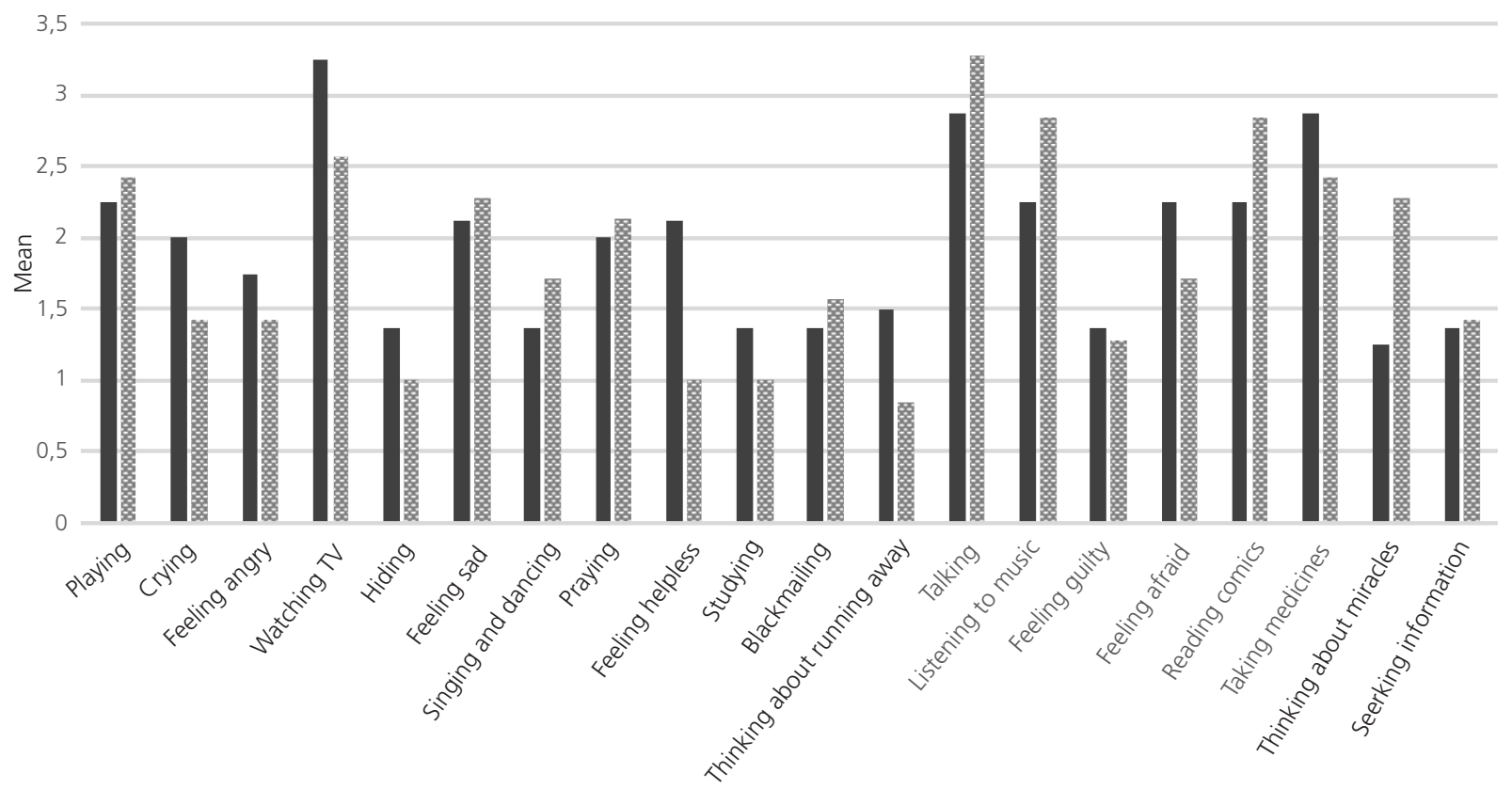

Coping behavior

Leukemia/Lymphoma Solid tumors

Figure 4. Mean of chemotherapy coping behaviors reported by children with cancer, separated by type of tumor (Leukemia/Lymphoma versus Solid Tumors). Botucatu and Bauru (SP), Brazil, 2015.

\section{Discussion}

The present study identified that children with cancer, in order to adapt to chemotherapy, reported resorting to behaviors with greater chances of an adaptive outcome (Motta et al., 2015) and common in children with chronic diseases and/or hospitalized: watching TV, talking and taking medicines (Caprini \& Motta, 2017; Carnier et al., 2015; Garioli et al., 2019; Hostert et al., 2015; Motta et al., 2015; Rocha et al., 2015; Silveira, Lima, \& Paula, 2018; Zimmer-Gembeck \& Skinner, 2011). However, confirming the literature (Carnier et al., 2015; Kristensen, Schaefer, \& Busnello, 2010; Motta et al., 2015; Zimmer-Gembeck \& Skinner, 2011), some specificities were observed and associated with sex, age, and type of cancer.

As in other studies with children with chronic diseases and/or hospitalized (Caprini \& Motta, 2017; Carnier et al., 2015; Garioli et al., 2018; Hostert et al., 2015; Motta et al., 2015; Silveira et al., 2018), the "taking medicines" coping behavior had a high frequency in the present study. It is a common behavior among children and adolescents (Motta et al., 2015; Zimmer-Gembeck \& Skinner, 2011), which can be classified, according to the MTC reference, in the macro category "problem solving", an attempt to try to modify the situation that caused stress (Lazarus \& Folkman, 1984). The high percentage of children who reported this 
behavior strengthens the hypothesis that the participants in this research had positive expectations regarding chemotherapy, possibly because they believe that this procedure increased their chances of cure, as pointed out by Cicogna et al. (2010).

The watching TV and talking behaviors are also recurrent in investigations with hospitalized children (Caprini \& Motta, 2017; Motta et al., 2015; Rocha et al., 2015). From the perspective of the MTC, talking, in most cases, signals the search for comfort or help, while watching TV is a behavior that aims at distracting (Motta, 2007; Motta et al., 2015). Both represent an effort to regulate the emotional state associated with stress (Lazarus \& Folkman, 1984), help the child to focus on pleasant situations instead of keeping the focus on the negative aspects of the hospital (Motta, Enumo, \& Ferrão, 2006).

The choice of more passive distraction techniques, in this context, is justified because dynamic activities, such as playing and dancing, are not viable during chemotherapy, due to the physical limitations imposed by the procedure or because the children were weakened by the effects of the medicines or by the evolution of the disease. In this sense, talking is a behavior that can be emitted in restrictive conditions and is facilitated by the presence of the person who is with them, or their guardian (Caprini \& Motta, 2017). Having a family member during the procedure, with whom you can talk to, has already been identified as a factor that can ease physical and emotional pain and has an important role in overcoming painful moments resulting from cancer treatment (Rocha et al., 2015).

Although watching TV is a more passive technique, and talking is a more interactive one, it was found that both increased pain tolerance in children exposed to invasive medical procedures (Motta \& Enumo, 2010). However, more studies are still needed to assess which of the two techniques can offer better results, as well as more studies on the most appropriate television content for different age groups (Motta, 2007; Motta \& Enumo, 2010). During the performance of this study it was observed that, in many moments, the TVs were not showing any content aimed at children and young individuals.

While escape or avoidance strategies, which include hiding and thinking about running away, are quite common in the repertoire of children and adolescents (Motta et al., 2015; Zimmer-Gembeck \& Skinner, 2011), they were rarely mentioned by children in the present study. Although these strategies seek to relieve stress, they are considered as non-facilitators, responsible for a more stressful adaptation to the situation, as they harm the collaboration between the child and the medical procedures (Motta et al., 2015). In addition to making little use of these strategies, the children who said they would like to run away seemed to be facing a conflict, so much so that after choosing this way of coping, they completed their speech by saying that it was only a wish, that they understood the need for treatment, in order to get cured.

Unlike other studies with hospitalized children who used the ACH, analyzed by Motta et al. (2015), the studying behavior was little mentioned by children undergoing chemotherapy, possibly because at the time of the research, most participants were not attending school. The interruption of education is common in patients in these conditions because they require long period of treatment, with difficulties to commute to the hospital and unfavorable physical conditions to keep attending school (Lanza \& Valle, 2014).

Regarding their sexes, a high percentage of girls reported the talking behavior during the procedure, which seems to show that girls seek support in interpersonal relationships to alleviate this stressful situation, confirming that girls tend to resort to prosocial strategies (Eschenbeck, Schmid, Schröder, Wasserfall, \& Kohlmann, 2018; Kristensen et al., 2010). On the other hand, boys often mentioned the taking medicines behavior, a facilitating strategy, but they also mentioned strategies considered to have a negative impact on adaptation, such as hiding and thinking about running away (Motta et al., 2015). In other studies, there were also differences between boys and girls in the use of coping strategies and behaviors (Carnier et al., 2015; Eschenbeck et al., 2018; Motta et al., 2015), which seems to reflect the forms of socialization and the 8 expectations of the role to be played by each sex, in the Western culture (Kristensen et al., 2010). 
Regardless of age, most children pointed to distracting strategies as the first choice to cope with the stress caused by chemotherapy sessions. However, the behaviors varied: the younger children gave preference to the playing behavior and, making a counterpoint, older children mentioned listening to music and talking. A systematic literature review found that, depending on age, there are differences in how to respond to psychological interventions to relieve pain or to control fear and anxiety during invasive and painful procedures (Birnie et al., 2015).

According to Motta et al. (2015), when playing, the child can attribute other meanings to their hospitalization experience, allowing the development of autonomy and a sense of competence. Through playing, young children can have the opportunity to reproduce real life conflicts, looking for, in a make-believe situation, solutions that satisfy and mitigate negative feelings. In games, children can express anger and frustration in the face of challenges, experiencing, in a safe environment, the consequences of their actions in alternative scenarios, developing a broader socioemotional repertoire to face the difficulties imposed by the disease and treatment (Nijhof et al., 2018).

Most of the older children, who mentioned listening to music and talking used their smartphones during chemotherapy sessions, even when the TV was on. The frequent media use by older children and adolescents was observed by Eschenbeck et al. (2018). It is a resource that allows them to listen to songs chosen by themselves through their headphones, as opposed to TV programs, whose selection was made by members of the team. The smartphone also facilitated conversations with other people through text messages and social networking apps and it has already been found that, especially for teenagers, self-selected distraction techniques seem to bring benefits for pain control (Chanthong \& Jirapaet, 2017). Finally, some children had games on their smartphones and there is evidence showing that they can help cope with the most harmful aspects of the treatment such as nausea, vomiting, fatigue, pain and anxiety (Nijhof et al., 2018). It can be assumed, then, that the use of smartphones by older children, whether to play games, listen to music or send messages, in addition to distracting, could be meeting the basic psychological needs of relationship and autonomy and, therefore, was associated with a likely positive developmental outcome (Ramos et al., 2015).

The feeling helpless behavior was reported by more than half (53\%) of children with leukemia/ lymphoma and had a low frequency in patients with solid tumors (26\%). The dismay of children with cancer can be understood to the extent that, compared to other chronic conditions such as asthma and diabetes, children with cancer experience more restrictions and limitations in their daily activities (going to school, going out with friends, etc.) which are often associated with negative feelings (Lima, Silva, \& Lemos, 2017). However, given the differences found in patients with different types of cancer, it is possible to conjecture that the difficulty of understanding leukemia, without a defined location in the body, with a treatment that can last from two to three years, with several readmissions and numerous chemotherapy sessions can alter the emotional state of patients and increase the distress and distrust of healing of children (Elman \& Silva, 2007; Lopes, Camargo, \& Bianchi, 2000). In contrast, the diagnosis of a solid tumor can be better understood because it can be located, if references are made to concrete elements in its description ("tiny lumps", nodes), several can be removed by means of surgery and the treatment usually takes less time (Borges, Lima, \& Dupas, 2016), facilitating the maintenance of hope in healing.

According to the theoretical framework of the MTC, discouragement would be related to the "helplessness" and "submission" macro categories, meaning that the procedure is being perceived as a threat to the needs for competence and autonomy (Motta et al., 2015) and that professionals will have to deal with this discouragement and skepticism, in addition to creating situations that provide the perception of self-control. For this, it will be necessary to plan interventions that restore confidence in the procedure and ensure adherence to treatment, especially in the initial phase of therapy, when children have to adapt to this new reality and face pain, physical changes and weakness (Cagnin, Ferreira, \& Dupas, 2003). Positive emotions such as optimism and hope, for example, can influence the way to deal with adversity, using strategies considered as facilitators to the adaptation process (Martins et al., 2018; Pagung et al., 2017). 


\section{Conclusion}

Before concluding, it is necessary to make some methodological considerations. Although two centers of excellence for cancer treatment were used to compose the sample, the study had a small number of participants, which was recurrent in other studies with children with cancer (Caprini \& Motta, 2017; Cicogna et al., 2010; Hostert et al., 2015; Lanza \& Valle, 2014; Lima, Barros, \& Enumo, 2014; Pagung et al., 2017; Sousa et al., 2014). Trying to get around the situation, the study included children who had recently finished their intravenous chemotherapy treatment, who were still in outpatient care and could remember the strategies used to cope with chemotherapy. Even so, the number of participants did not allow the use of statistical treatments that could allow a more in-depth analysis of the data.

Taking into account that the participants were weakened by the disease and treatment, it was decided to avoid making patients travel further, so data collection took place in the environment where the chemotherapy sessions were held, often with the presence of the legal guardian during the application. On the one hand, their presence may have impaired privacy, making the child uncomfortable to answer some questions, but on the other hand, the guardian stay with the child may have reduced anxiety and they could hear reports about subjects that they had never addressed, with possible repercussions on their own communication with their children. As an example, the guardians were quite surprised when children justified the behavior of "blackmailing" in the $\mathrm{ACH}$, because they realized that, with this, they obtained personal gains and advantages.

In relation to the collection instrument, the use of the $\mathrm{ACH}$ proved to be appropriate to the context, since the participants identified themselves with the characters on the pictures and rated the instrument as "fun". However, younger children had difficulty justifying the choices of behaviors referred to in the ACH, which made it difficult to identify strategies and macro categories.

Therefore, in general, the results seem to signal that, in the chemotherapy process, it is necessary to provide resources that facilitate children's distraction, pointed out both in the literature and by them, as the coping strategy that most helps in their adaptation to the treatment. These resources should, preferably, be interactive and allow different choices depending on the child's age, sex, and type of diagnosis. Even in the face of the need for further studies, it is hoped that the data from this research can contribute to the planning of multi-professional and humanized care in the treatment of children with cancer, undergoing chemotherapy.

\section{Contributors}

F. H. P. PADOVANI, G. C. LOPES, and G. B. PEROSA were responsible for the conception and research's design. All authors also contributed to the data analysis and interpretation, discussion of the results, review and approval of the final version of the article.

Antoniazzi, A. S., Dell'Aglio D. D., \& Bandeira, D. R. (1998). O conceito de coping: uma revisão teórica. Estudos de Psicologia (Natal), 3(2), 273-294. http://dx.doi.org/10.1590/S1413-294X1998000200006

Birnie, K. A., Chambers, C. T., Taddio, A., McMurtry, C. M., Noel, M., Riddell, R. P., \& Shah, V. (2015). Psychological interventions for vaccine injections in children and adolescents. The Clinical Journal of Pain, 31 (Suppl 10), s72-s89. https://doi.org/10.1097/AJP.0000000000000265

Borges, A. A., Lima, R. A. G., \& Dupas, G. (2016). Segredos e verdades no processo comunicacional da família com a criança com câncer. Escola Anna Nery, 20(4), e20160101. https://doi.org/10.5935/1414-8145.20160101 
Cagnin, E. R. G., Ferreira, N. M. L., \& Dupas, G. (2003). Vivenciando o câncer: sentimentos e emoções da criança. Acta Paulista de Enfermagem, 16(4), 18-30.

Caprini, F. R., \& Motta, A. B. (2017). Childhood cancer: diagnosis impact analysis. Psicologia: Teoria e Prática, 19(2), 177-189. http://dx.doi.org/10.5935/1980-6906/psicologia.v19n2p174-186

Carnier, L. E., Padovani, F. H. P., Perosa, G. B., \& Rodrigues, O. M. P. R. (2015). Estratégias de enfrentamento em crianças em situação pré-cirúrgica: relação com idade, sexo, experiência com cirurgia e estresse. Estudos de Psicologia (Campinas), 32(2), 319-330. http://dx.doi.org/10.1590/0103-166X2015000200015

Chanthong, P., \& Jirapaet, V. (2017). The effect of self-selected distraction technique on the pain caused by venipuncture in early adolescents with cancer. Journal of Health Research, 31(3), 171-176. https://doi.org/10.14456/jhr.2017.21

Cicogna, E. C., Nascimento, L. C., \& Lima, R. A. G. (2010). Crianças e adolescentes com câncer: experiências com a quimioterapia. Revista Latino-Americana de Enfermagem, 18(5), 864-872. https://doi.org/10.1590/S010411692010000500005

Elman, I., \& Silva, M. E. M. P. (2007). Crianças portadoras de leucemia linfóide aguda: análise dos limiares de detecção dos gostos básicos. Revista Brasileira de Cancerologia, 53(3), 297-303.

Eschenbeck, H., Schmid, S., Schröder, I., Wasserfall, N., \& Kohlmann, C. W. (2018). Development of coping strategies from childhood to adolescence. European Journal of Health Psychology, 25(10), 18-30. https://doi.org/10.1027/251 2-8442/a000005

Garioli, D. S., Paula, K. M. P., \& Enumo, S. R. F. (2019). Avaliação do coping da dor em crianças com anemia falciforme. Estudos de Psicologia (Campinas), 36, e160079. https://doi.org/10.1590/1982-0275201936e160079

Hostert, P. C. C. P., Motta, A. B., \& Enumo, S. R. F. (2015). Coping da hospitalização em crianças com câncer: a importância da classe hospitalar. Estudos de Psicologia (Campinas), 32(4), 627-639. https://doi.org/10.1590/0103-1 66X2015000400006

Jesus, L. K. R., \& Gonçalves, L. L. C. (2006). O cotidiano de adolescentes com leucemia: o significado da quimioterapia. Revista de Enfermagem UERJ, 14(4), 545-550.

Kristensen, C. H., Schaefer, L. S., \& Busnello, F. de B. (2010). Estratégias de coping e sintomas de stress na adolescência. Estudos de Psicologia (Campinas), 27(1), 21-30. https://doi.org/10.1590/S0103-166X2010000100003

Lanza, L. F., \& Valle, E. R. M. (2014). Criança no tratamento final contra o câncer e seu olhar para o futuro. Estudos de Psicologia (Campinas), 31(2), 289-297. https://doi.org/10.1590/0103-166X2014000200013

Lazarus, R. S., \& Folkman, S. (1984). Stress, appraisal, and coping. New York: Springer.

Lima, A. S., Barros, L., \& Enumo, S. R. F. (2014). Enfrentamento em crianças portuguesas hospitalizadas por câncer: comparação de dois instrumentos de avaliação. Estudos de Psicologia (Campinas), 31(4), 559-571. https://doi. org/10.1590/0103-166X2014000400010

Lima, L., Silva, V., \& Lemos, M. S. (2017). How chronic disease affects children's views on being ill and healthy: a comparative study. Scandinavian Journal of Caring Sciences, 31, 922-929. https://doi.org/10.1111/scs.12415

Lopes, L. F., Camargo, B., \& Bianchi, A. (2000). Os efeitos tardios do tratamento do câncer infantil. Revista da Associação Médica Brasileira, 46(3), 277-284. https://doi.org/10.1590/S0104-42302000000300014

Martins, A. R., Crespo, C., Salvador, A., Santos, S., Carona, C., \& Canavarro, M. C. (2018). Does hope matter? Associations among self-reported hope, anxiety, and health-related quality of life in children and adolescents with cancer. Journal of Clinical Psychology in Medical Settings, 25(1), 93-103. https://doi.org/10.1007/s10880-018-9547-x

Motta, A. B. (2007). Brincando no hospital: uma proposta de intervenção psicológica para crianças internadas com câncer (Tese de doutorado não-publicada). Universidade Federal do Espírito Santo.

Motta, A. B., \& Enumo, S. R. F. (2004). Câncer infantil: uma proposta de avaliação das estratégias de enfrentamento da hospitalização. Estudos de Psicologia (Campinas), 21(3), 193-202. https://doi.org/10.1590/S0103-166X2004000300004

Motta, A. B., \& Enumo, S. R. F. (2010). Intervenção psicológica lúdica para o enfrentamento da hospitalização em crianças com câncer. Psicologia: Teoria e Pesquisa, 26(3), 445-454. https://doi.org/10.1590/S0102-37722010000300007

Motta, A. B., Enumo, S. R. F., \& Ferrão, E. S. (2006). Avaliação das estratégias de enfrentamento da hospitalização em crianças com câncer. In M. B. M. Linhares, M. A. Crepaldi, \& G. B. Perosa (Orgs.), Temas em Psicologia Pediátrica (pp.191-217). São Paulo: Casa do Psicólogo.

Motta, A. B., Perosa, G. B., Barros, L., Silveira, K. A., Lima, A. S. S., Carnier, L. E., ... Caprini, F. R. (2015). Comportamentos de coping no contexto da hospitalização infantil. Estudos de Psicologia (Campinas), 32(2), 331-341. https://doi. org/10.1590/0103-166X2015000200016 
Nijhof, S. L., Vinkers, C. H., van Geelen, S. M., Duijff, S. N., Achterberg, E. J. M., van der Net, J., ... Lesscher, H. M. B. (2018). Healthy play, better coping: the importance of play for the development of children in health and disease. Neuroscience and Biobehavioral Reviews, 95, 421-429. https://doi.org/10.1016/j.neubiorev.2018.09.024

Oliveira, C. G. T., Enumo, S. R. F., \& Paula, K. M. P. (2017). A psychological intervention proposal on coping with pain for children with Sickle Cell Disease. Estudos de Psicologia (Campinas), 34(3), 355-366. https://doi.org/10.1590/1982-0 2752017000300004

Pagung, L. B., Canal, C. P. P., Missawa, D. D. A., \& Motta, A. B. (2017). Estratégias de enfrentamento e otimismo de crianças com câncer e crianças sem câncer. Revista Psicologia e Saúde, 9(3), 33-46. https://doi.org/10.20435/pssa.v9i3.470

Ramos, F. P., Enumo, S. R. F., \& Paula, K. M. P. (2015). Teoria Motivacional do Coping: uma proposta de análise do enfrentamento do estresse. Estudos de Psicologia (Campinas), 32(2), 269-279. https://doi.org/10.1590/0103-1 66X2015000200011

Rocha, A. F. P., Sposito, A. M. P., Botoli, P. S., Silva-Rodrigues, F. M., Lima, R. A. G. de, \& Nascimento, L. C. (2015). O alívio da dor oncológica: estratégias contadas por adolescentes com câncer. Texto e Contexto Enfermagem, 24(1), 96-104. http://dx.doi.org/10.1590/0104-07072015002120013

Silveira, K. A., Lima, V. L., \& Paula, K. M. P. (2018). Estresse, dor e enfrentamento em crianças hospitalizadas: análise de relações com o estresse do familiar. Revista da SBPH, 21(2), 5-21.

Souza, M. L. X. F., Reichert, A. P. S., Sá, L. D., Assolini, F. E. P., \& Collet, N. (2014). Adentrando em um novo mundo: significado do adoecer para a criança com câncer. Texto e Contexto Enfermagem, 23(2), 391-399. https://doi. org/10.1590/0101-07072014000710013

Spirito, A., Stark, L. J., \& Williams, C. (1989). Development of a brief coping checklist for use with pediatric populations. Journal of Pediatric Psychology, 13(4), 555-574.

Vasconcelos, A. G., \& Nascimento, E. (2016). Teoria Motivacional do Coping: um modelo hierárquico e desenvolvimental. Avaliação Psicológica, 15, 77-87. https://doi.org/10.15689/ap.2016.15ee.08

Zimmer-Gembeck, M. J., \& Skinner, E. A. (2011). The development of coping across childhood and adolescence: an integrative review and critique of research. International Journal of Behavioral Development, 35(1), 1-17. https://doi. org/10.1177/0165025410384923

Received: September 5, 2019

Final version: February 20, 2020

Approved: April 27, 2020 